\title{
ІНФОРМАТИЗАЦІЯ ЕКОНОМІКИ ТА ІНФОРМАЦІЙНЕ СУСПІЛЬСТВО
}

\section{Гнатенко В. С.}

\section{ВСТУП}

Стрімкий розвиток i поширення нових інформаційних $\mathrm{i}$ телекомунікаційних технологій нині набувають характеру глобальної інформаційної революції, яка впливає на політику, економіку, управління, фінанси, науку, культуру й інші сфери життєдіяльності суспільства в рамках національних кордонів і в світі загалом.

Однією 3 головних умов побудови інформаційної економіки $\epsilon$ здійснення масштабної інформатизації суспільства, яка буде спроможна гарантувати умови створення і швидкого поширення нових знань, що перетворюються на головну рушійну силу економічного i соціального розвитку. Належне інформаційне забезпечення все більше набуває важливого значення та має відповідати вимогам сьогодення, адже саме інформація разом із наукою та інтелектом людини породжує нові знання, починає поступово змінювати устої сучасного суспільства, надає йому ознак суспільства нового типу - інформаційного. У зв'язку 3 цим виникає необхідність дослідження системної взаємодії інноваційних та інформаційних чинників розвитку суспільства i визначення механізмів ї практичного застосування. 3 огляду на це проблема здійснення інформатизації суспільства в умовах інноваційних зрушень набуває особливої актуальності.

Натепер в Україні існує нагальна потреба в удосконаленні механізмів реалізації державної політики в сфері інформаційної економіки. У повсякденному житті громадян, державному управлінні, економіці все більше набувають важливого значення електронні послуги, інформація. Важливим є не тільки зміст цієї інформації, а й спосіб іiі отримання. 3 кожним роком зростає масштаб застосування інформаційних технологій, обсяг електронних послуг, відбуваються зміни в інфраструктурі, технологіях. Ці процеси спричинили зміни у суспільстві, відбувся перехід до інформаційного суспільства та інформаційної економіки.

\section{1. Теоретичні аспекти інформатизації економіки та суспільства}

Нині проблема, пов'язана 3 інформатизацією суспільства, є дуже актуальною, оскільки рівень використання інформаційно- 
телекомунікаційних технологій (далі - IКТ) $є$ одним із головних чинників економічного зростання i підвищення конкурентоспроможності держави на світовій економічній та політичній арені; інформатизація зумовлює ефективність соціально-економічного i політичного розвитку держави, створює нові формати взаємодії влади i суспільства, влади і бізнесу; сприяє соціальній інтеграції та мирному співіснуванню різних соціальних інститутів і груп всередині держави.

3 другої половини XX століття в цивілізованому світі відбувається істотне збільшення значення і ролі інформації в рішенні практично всіх завдань світової спільноти. Це $\epsilon$ переконливим доказом того, що науково-технічна революція поступово перетворюється в інтелектуально-інформаційну.

Сьогоднішній етап розвитку цивілізації характеризується становленням глобального інформаційного суспільства, в якому основним стратегічним ресурсом $\epsilon$ інформація. Нові інформаційнокомунікаційні технології все більше проникають практично в усі сфери життєдіяльності суспільства, змінюючи умови праці і побуту людини, формуючи в ньому нові потреби, стереотипи поведінки, а також нові уявлення про якість життя, простір і час ${ }^{1}$.

Інформатизація $\epsilon$ комплексним процесом інформаційного забезпечення соціально-економічного, політичного i культурного розвитку суспільства на базі сучасних інформаційних технологій i відповідних технічних засобів. Процес інформатизації суспільства носить глобальний характер і спрямовується на формування єдиного інформаційного простору (інфосфери). Цей процес супроводжується лавиноподібним накопиченням інформаційних ресурсів. В його основі лежить використання нових інформаційних технологій (насамперед телекомунікаційних). Інформатизація виникла через кардинальної зміни ролі інформації, вона прямо та опосередковано впливає на розвиток науки, продуктивних сил і соціальної сфери суспільства.

Процес інформатизації суспільства характеризується такими основними рисами:

1) глобальністю і масштабністю;

2) наступністю;

3) високими темпами;

4) децентралізацією, об'єктивною незалежністю і відкритістю;

5) комплексністю;

6) нерівномірністю.

1 Панченко О.А., Панченко Л.В. Інформаційна безпека та інформаційна культура в сучасному інформаційному суспільстві. Правова інформатика. 2015. № 2(46). C. 32-38. 
Нині проблема інформатизації суспільства (поряд 3 проблемами безпеки, екології та іншими) стала пріоритетною, і iii значення в суспільстві постійно зростає. Процес формування інформаційного суспільства був тривалим, він пройшов кілька етапів свого становлення. Інформатизація двояко впливає на суспільне життя. Інформатизація - це отримання нових знань, комунікація, швидкий доступ до будь-якої інформації, що сприяє розвитку економіки, соціальної сфери життєдіяльності, але вона має негативний вплив як на окремих людей, так і на суспільство загалом.

Під інформатизацією суспільства прийнято розуміти організований соціально-економічний i науково-технічний процес створення оптимальних умов для задоволення інформаційних потреб громадян, органів державної влади, органів місцевого самоврядування, організацій, громадських об'єднань на основі формування i використання інформаційних ресурсів. На початку 1960 -х років фактично одночасно в Японії і США був введений у науковий обіг термін «інформаційне суспільство», який поклав початок однойменної концепції, яку почали розробляти М. Порат ${ }^{2}$, Й. Масуда $^{3}$, Т. Стоуньер ${ }^{4}$, Р. Катц ${ }^{5}$.

У вітчизняній та зарубіжній економічній літературі здійснено фундаментальні дослідження, які стосуються висвітлення засад формування та особливостей функціонування майбутнього постіндустріального (інформаційного) суспільства. Складником цих досліджень $є$ наукові надбання вчених, орієнтовані на вивчення конкретних форм вияву процесу інформатизації суспільства, її технікотехнологічних і соціально-економічних аспектів, умов створення та отримання інформаційної продукції, засобів регулювання інформаційних потоків тощо. Саме цим напрямам наукових досліджень присвятили свої праці І. Арістова ${ }^{6}$, Л. Довгань ${ }^{7}, \Gamma$. Жаворонкова ${ }^{8}$, А. Литвин ${ }^{9}$, В. Плескач ${ }^{10}$, В. Тамбовцев ${ }^{11}$, Л. Федулова ${ }^{12}$ та інші.

${ }^{2}$ Porat M., Rubin M. The Information Economy: Development and Measurement. Wash., 1978.

${ }^{3}$ Masuda Y. The Information Society as Post-Industrial Society. Wash., 1981.

${ }^{4}$ Stonier T. The Wealth of Information. L., 1983.

${ }^{5}$ Katz R.L. The Information Society: An International Perspective. N.Y., 1988.

${ }^{6}$ Арістова I.В. Державна інформаційна політика: організаційно-правові аспекти : монографія / за заг. ред. д. ю. н., професора О.М. Бандурки. Х. : УВС, 2000. 368 с.

7 Довгань Л.С., Малик І.П. Інституціональні аспекти розвитку інформаційної економіки. Економічний вісник Національного технічного університету Украйни «Київський політехнічний інститут». 2013. № 10. С. 3-9.

8 Жаворонкова Г.В., Борисюк І.О. Розвиток інноваційних інформаційнокомп'ютерних технологій в Україні. Формування ринкових відносин в Украӥні. 2008. № 3. С. 68-72.

9 Литвин А.Є. Особливості розвитку галузі інформаційних технологій. 
Незважаючи на досить широку концептуальну базу дослідження інформаційної економіки, багато теоретико-методологічних питань залишаються дискусійними і потребують подальшого уточнення та обгрунтування, зокрема вимагають уточнення питання, які стосуються сучасного стану інформаційної економіки в Україні, а також перспектив ії розвитку в державі.

На думку Л. Довгань та I. Малик, розбудова інформаційної економіки має здійснюватися насамперед шляхом консолідації інформаційно-технологічних і комунікаційних галузей, які розвиваються бурхливими темпами, та сучасних високотехнологічних матеріальних виробництв, тісно пов'язаних із процесами інформатизації суспільства ${ }^{7}$.

Головними характеристиками інформаційного суспільства, на думку I. Арістової, є інформаційна економіка, індустрія інформаційних послуг, сучасні інтелектуальні інформаційні технології та технології зв'язку, значний потенціал науки, потреба фізичних та юридичних осіб в інформації (знаннях), високий рівень інформаційно-правової культури всіх суб'єктів інформаційних відносин, матеріально-технічне забезпечення різноманітних послуг ${ }^{6}$.

Зарубіжні і вітчизняні дослідники єдині в тому, що якісні зміни в економічній, соціально-політичній і духовній сферах суспільного життя зумовлені інтенсивним розвитком i використанням сучасних інформаційно-комунікаційних технологій, вони визначили рух людства до нової, постіндустріальної фази розвитку - інформаційного суспільства.

Відмінними рисами інформаційного суспільства є:

1) суттєве збільшення у валовому внутрішньому продукті частки галузей економіки, пов'язаних із виробництвом знань, зі створенням i впровадженням наукомістких, в тому числі інформаційних, технологій, інших продуктів інтелектуальної діяльності, 3 наданням послуг в області інформатизації, освіти, зв'язку, а також в області пошуку, передачі, отримання та поширення інформації (інформаційних послуг);

2) прискорення науково-технічного прогресу i перетворення наукових знань у реальний фактор виробництва, підвищення якості життя людини і суспільства;

Актуальні проблеми економіки. 2011. № 11(125). С. 300-307.

${ }_{10}$ Плескач В. Проблеми становлення електронних ринків в умовах розвитку інформаційного суспільства. Науково-технічна інформація. 2008. № 2. С. 45-48.

11 Тамбовцев В.Л. Пятый рынок: экономические проблемы производства информации. М. : МГУ, 2006. 127 с.

12 Федулова Л.І. Тенденції розвитку інноваційної політики та іiі вплив на економічне зростання. Економіка і прогнозування. 2011. № 2. С. 63-81. 
3) участь значної частини працездатного населення у виробничій діяльності, пов'язаній зі створенням і використанням інформаційних технологій, інформації і знань;

4) суттєве розширення можливостей громадян із пошуку, накопичення, передачі, виробництва та розповсюдження інформації і знань;

5) глобалізація економічної, політичної та духовної сфер життя суспільства;

6) поряд iз розширенням творчих можливостей особистості i суспільства інтенсивний розвиток інформаційно-комунікаційних технологій створює нові можливості для реалізації загроз національній безпеці, пов'язаних із порушенням встановлених режимів використання інформаційних та комунікаційних систем, утиском конституційних прав громадян, використанням можливостей сучасних інформаційних технологій для здійснення ворожих, а також терористичних атак ${ }^{13}$.

В інформаційному суспільстві ділова активність перетікає в інформаційно-комунікативне середовище. Формуються віртуальна економіка, віртуальна фінансова система, що ставить складні питання про механізми їx регулювання i саморегулювання. Інформаційне суспільство формується як глобальне. Воно включає в себе:

1) світову «інформаційну економіку» i розвинені системи електронної комерції;

2) єдиний світовий інформаційний простір;

3) глобальну інформаційну інфраструктуру;

4) світову нормативно-правову систему ${ }^{14}$.

Інформаційне суспільство - це суспільство 3 високим рівнем розвитку i використання інформаційних технологій, розвиненими інфраструктурами, які забезпечують виробництво інформаційних ресурсів і можливість доступу до інформації.

В сучасній економіці інформація відіграє величезну роль. Вона революціонізувала, модифікуючи практично всі сторони економічного життя. Тому ринкову економіку нині не можна охарактеризувати, ігноруючи той факт, що формується новий технологічний тип виробництва - економіка, яка грунтується на цифрових технологіях, засобах обчислювальної техніки, новітніх видах телекомунікацій, мережевих інформаційних технологіях. Утворюється також потужний інформаційний та інформаційно-фінансовий сектор економіки, відбувається впровадження інформаційних технологій у різні галузі.

\footnotetext{
13 Журавлева И.А. Информационное общество : учебное пособие. Иркутск : Издво Иркут. гос. ун-та, 2013. 141 с.

14 Чугунов А.В. Развитие информационного общества: теории, концепции и программы : учебное пособие. СПб : Ф-т филологии и искусств СПбГУ, 2007. 98 с.
} 
Нині існують різні інтерпретації терміну “інформаційна економіка», які залежать від погляду конкретного дослідника та його способу дослідження. Поширеним є розуміння інформаційної економіки як такої фази розвитку суспільства, в якій головними продуктами виробництва $\epsilon$ інформація та знання. Особливостями $є$ збільшення ролі інформації та знань в житті суспільства, зростання частки інформаційних комунікацій, продуктів і послуг у ВВП країни, створення глобального інформаційного простору, де відбувається ефективна інформаційна взаємодія людей, зокрема i завдяки ї доступу до світових інформаційних ресурсів i споживанню відповідних інформаційних продуктів і послуг ${ }^{15}$.

Таким чином, інформаційна економіка - це економіка інформаційного суспільства, яка $є$ сукупністю галузей, що виробляють $\mathrm{i}$ поширюють товари та послуги 3 використанням інформаційнокомунікаційних технологій. Інформаційне суспільство формується в процесі інформатизації. Інформатизація $\epsilon$ соціально-економічним i науково-технологічним процесом масового застосування інформаційно-комунікаційних технологій в усіх сферах людської діяльності (економіка, політика, культура, освіта, наука, оборона) для кардинального поліпшення умов праці і якості життя населення, значного підвищення ефективності всіх видів виробництва.

Виходячи 3 наведених вище теоретичних положень, зазначу основні ознаки інформаційної економіки на сучасному етапі розвитку:

1) знання та інформація, закладені в продукцію і послугу, що складають частину вартості, яка відбивається в інноваційному складнику ціни продукту, послуги;

2) доля зайнятих на ринку праці неухильно збільшується серед працівників сфери обробки знань та інформації;

3) у виробничих процесах все більше набувають значення інформаційні технології, пов'язані 3 формуванням і реалізацією інформації;

4) зростання ролі інформаційних менеджерів в розвитку і наданні інформації як способу зменшення помилок у стратегічному плануванні господарської діяльності організацій.

Безумовно, інформаційні технології i інформаційна техніка докорінно змінили наше життя. Те, що раніше було фантастикою, зараз стає реальністю ${ }^{16}$. Інформаційно-комунікаційні технології істотно

15 Бажал Ю. Інформаційна економіка. Роль інформації у формуванні ринкової економіки. К. : K.I.C, 2004. C. 33-57. URL: http://www.ekmair.ukma.kiev.ua/bitstream/ 123456789/2430/1/Bazhal_Informatsiyna_ekonomika.pdf (дата звернення: 24.05.2020).

${ }^{16}$ Роль конвергентных технологий в становлении непрерывного благополучия в неоиндустриальной экономике / Доценко Е. Ю., Жиронкина О. В., Агафонов Ф. В., Генин А. Е. Путеводитель предпринимателя. 2016. № 32. С. 65-79. 
впливають і на розвиток традиційних галузей економіки, наприклад адитивне виробництво, використання промислових роботів, індустріальний інтернет та інтернет речей (Internet of Things). Взаємозв'язок розвитку інформатизації 3 розвитком суспільства наведені на Рисунку 1.

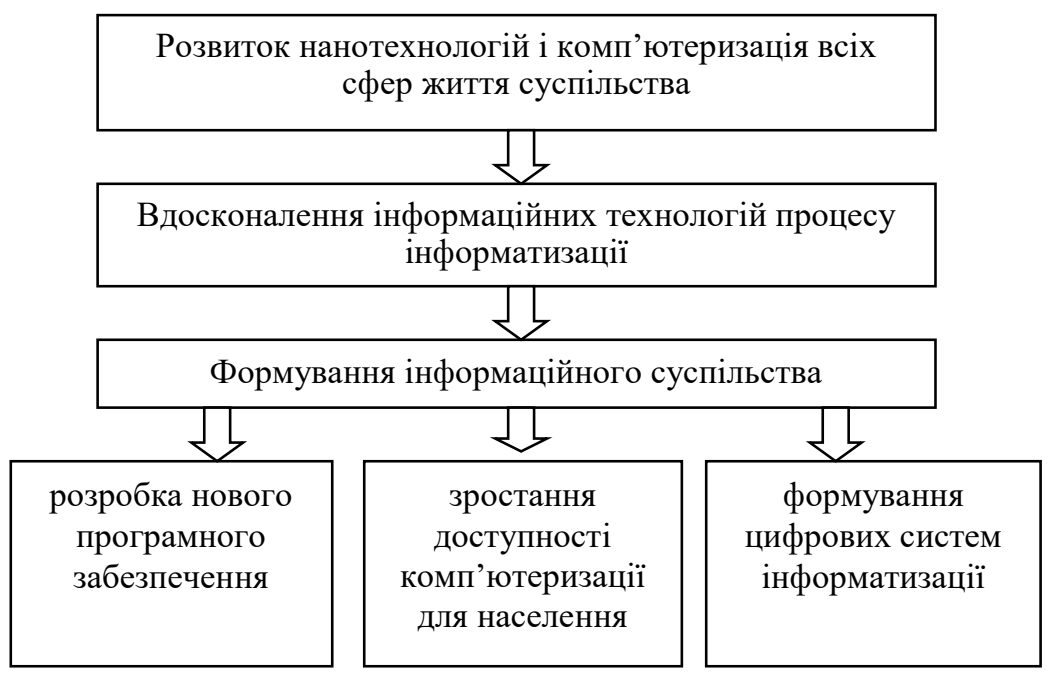

\section{Рис. 1. Взасмозв'язок розвитку інформатизації з розвитком суспільства}

На думку Б. Кристального, до основних ознак інформаційного суспільства можна віднести такі:

1) кожний член суспільства має можливість своєчасно та оперативно отримувати за допомогою глобальних інформаційних мереж повну та достовірну інформацію будь-якого виду та призначення з будь-якої держави при перебуванні практично в будь-якій частині географічного простору;

2) реалізується можливість оперативної, майже миттєвої комунікації не лише кожного члена суспільства, а й певних груп населення 3 державними та суспільними структурами незалежно від місця проживання;

3) трансформується діяльність ЗМІ за формою створення та поширення інформації, розвивається та інтегрується до інформаційних мереж цифрового телебачення. Формується нове середовище - мультимедіа, в якому поширюється також інформація із традиційних 3MI; 
4) зникають географічні та геополітичні кордони держав у рамках інформаційних мереж, відбувається «зіткнення» та «ламання» законодавства країн ${ }^{17}$.

Широке використання нових інформаційних технологій у повсякденному житті сприяє вдосконаленню демократичних засад, призводить до підвищення політичної активності громадян, встановлення ефективного діалогу держави та громадськості 3 подальшим зворотнім зв'язком. Загалом процес становлення інформаційного суспільства вимагає від держави нових вимог, покликаних бути координаторами діяльності суб'єктів суспільства та сприяти створенню сприятливих умов інтеграції громадян країни у глобальне інформаційне суспільство, відстоювати власні інтереси в світовому інфопросторі ${ }^{18}$.

Становлення і розвиток інформаційної економіки - процес складний i суперечливий, що насамперед пов'язано із залежністю його від дії низки умов, наприклад глобалізація; розвиток людського капіталу; впровадження інформаційно-комунікаційних технологій; відкритість економіки; державне і нормативно-правове регулювання інформаційної галузі; географічні, соціально-економічні, політичні й інші особливості країни. Таким чином, подальший розвиток держави нерозривно пов'язаний із формуванням і розвитком інформаційного суспільства.

\section{2. Механізми розвитку інформаційної економіки в Україні}

Система управління економікою в Україні перебуває у процесі змін, що вимагає вдосконалення механізму державного управління економікою загалом та інформаційною економікою зокрема. Потрібно розробити принципово нові підходи до форми методів управління. $€$ необхідність у визначенні науково обгрунтованих нормативноправових аспектів державного регулювання. Організаційно-економічна структура суб'єктів господарювання у сфері інформаційної економіки в умовах глобалізації та інноваційного розвитку вже не відповідає сучасним об'єктивним потребам українського суспільства, тому виникає необхідність у ефективному інформаційному забезпеченні суспільства.

Незважаючи на те, що Закон України «Про інформацію» ${ }^{19}$ був прийнятий ще в 1992 році, аналізуючи і виділяючи характерні ознаки інформаційної економіки, вітчизняні науковці визначили, що

${ }^{17}$ Кристальный Б., Нестеров Ю. Информационное общество, информационная политика, правовая информационная защита. Информационное общество. 1997. № 1. C. 9-12.

${ }_{18}$ Арістова І.В. Державна інформаційна політика: організаційно-правові аспекти : монографія / за заг. ред. д. ю. н., професора О.М. Бандурки. Х. : УВС, 2000. 368 с.

19 Про інформацію : Закон України від 02.10.1992 № 2657-ХІІ / Верховна Рада України. URL: https://zakon.rada.gov.ua/laws/show/2657-12 (дата звернення: 26.05.2020). 
пріоритетність розвитку інформаційної економіки на найвищому рівні управління в Україні регламентована лише з 2007 року. Саме тоді був прийнятий окремий законодавчий документ, в якому було визначено завдання, цілі та напрями розвитку інформаційного суспільства в Україні, - Закон України «Про Основні засади розвитку інформаційного суспільства в Україні на 2007-2015 роки» ${ }^{20}$.

Цей закон став концептуальною основою для розробки завдань щодо розвитку інформаційного суспільства в Україні. В ньому чітко прописано завдання, цілі та напрями розвитку інформаційного суспільства, а також основи національної політики в цьому контексті. Наголошено на необхідності законодавчого забезпечення, організаційно-правових основ розвитку інформаційної економіки (інституційних, організаційних, ресурсних), окреслено потребу в механізмах інтеграції України у світовий інформаційний простір.

Наступним важливим документом, який визначає необхідність розвитку інформаційного суспільства, $є$ Стратегія розвитку інформаційного суспільства в Україні ${ }^{21}$ (далі - Стратегія), прийнята у 2013 році. Ця Стратегія визначає мету, базові принципи, стратегічні цілі розвитку інформаційного суспільства в Україні, завдання, спрямовані на їх досягнення, а також основні напрями, етапи і механізм реалізації цієї Стратегії 3 урахуванням сучасних тенденцій та особливостей розвитку України.

Так, цими документами та іншими нормативно-правовими актами визначено необхідність розвитку інформаційного суспільства, орієнтованого на інтереси людей, відкритого для всіх, в якому кожна людина може створювати і накопичувати інформацію та знання, мати до них вільний доступ, користуватися і обмінюватися ними, мати можливість повністю реалізувати свій потенціал, сприяти суспільному i особистісному розвиткові та підвищувати якість життя.

Одним зі складників загальнодержавної економічної політики $\epsilon$ політика держави щодо розвитку інформаційного суспільства, яка i визначає принципи державного управління розвитком інформаційної економіки. Насамперед необхідно розглядати механізми державного управління.

«Механізми державного управління - це складна система державних органів, організованих відповідно до визначених принципів

20 Про основні засади розвитку інформаційного суспільства в Україні на 2007-2015 роки : Закон України від 09.01.2007 № 537-V. / Верховна Рада України. URL: https://zakon.rada.gov.ua/laws/show/537-16 (дата звернення: 26.05.2020).

${ }^{21}$ Про схвалення Стратегії розвитку інформаційного суспільства в Україні : Розпорядження Кабінету Міністрів України; Стратегія від 15.05.2013 № 386-P. URL: https://zakon.rada.gov.ua/laws/show/386-2013-\%D1\%80 (дата звернення: 26.05.2020). 
для здійснення завдань державного управління, «інструмент» реалізації виконавчої влади держави. Механізм формування й реалізації державного управління - це сукупність i логічний взаємозв'язок соціальних елементів, процесів і закономірностей, які дозволяють суб'єкту державного управління «схоплювати» потреби, інтереси і цілі суспільства в керуючих впливах, закріплювати їх у своїх управлінських рішеннях, діях i практично втілювати їх у життя, незважаючи на державну владу» ${ }^{22}$.

Органи державної влади впливають на суспільство, виробництво, будь-яку соціальну систему для досягнення поставлених цілей. Це відбувається завдяки системі політичних, економічних, соціальних, організаційних і правових засобів цілеспрямованого впливу органів державного управління. Механізми державного управління - це практичні заходи, засоби, важелі, стимули. Структура механізму державного управління включає цілі, рішення, вплив, дії, результати. Таким чином, механізми державного управління поділяють залежно від суб'єктів управління. На вищому рівні - Верховна Рада України, Президент України, Кабінет Міністрів України. На обласному рівні обласні ради, обласні державні адміністрації. На районному рівні районні ради, районні державні адміністрації, на місцевому - міські, селищні, сільські ради.

Серед механізмів розвитку інформаційної економіки також слід розглядати партнерство і конкуренцію. Конкуренція, як механізм розвитку сфери інформаційної економіки, створює середовище для виникнення підприємництва нового типу. Таке підприємництво діє в умовах глобальності, високої продуктивності i зміни способу отримання прибутку. Глобальність дає можливість суб'єктам господарювання працювати як єдине ціле в реальному часі у світовому масштабі. Капітал вільно переміщається між країнами, а країни можуть використовувати цей капітал у реальному часі.

Висока продуктивність виникає завдяки використанню всіх видів ресурсів без часових і територіальних обмежень. Відбувається отримання ефекту масштабу на використання швидкості інновацій та здатності залучати й утримувати клієнтів. Розвиток сфери інформаційної економіки також залежить від появи нових виробничих сил, які суттєво змінюють матеріально-технічну базу виробництва за рахунок привнесення в неї автоматизації, інформаційних ресурсів та комп'ютерної техніки з глобальною мережею Інтернет. Відбуваються структурні зміни на макро- і мікроекономічному рівнях. На мікрорівні

22 Атаманчук Г.В. Теория государственного управления : курс лекций. М. : Юрид. лит., 1997. 400 с. 
така зміна означає появу підприємництва нового типу, яке функціонує в мережі Інтернет, використовує окремо функціонуючих i територіально відокремлених працівників, а також майже не має матеріальних активів (так працюють віртуальні корпорації).

Нині в Україні ринок інформаційних продуктів і послуг знаходиться на стадії формування. Щоб прискорити розвиток цього ринку, гнучке управління i новий державний менеджмент мають замінити централізований адміністративний контроль. Від політики обмеження монополізму має відбутися швидкий перехід до створення умов вільного підприємництва та інвестування, розвитку конкурентного середовища, інноваційної діяльності.

Натепер питання механізмів державного управління щодо розвитку інформаційної економіки в Україні залишається малодослідженим. Зважаючи на те, що інформаційна економіка в світі набуває значних темпів розвитку, а в Україні цей процес відбувається значно повільніше, визначення особливостей механізмів державного управління та пропозицій щодо державної підтримки та розвитку інформаційної економіки в Україні стає все більш актуальним.

Останніми роками в країні створені серйозні передумови і умови для формування й розвитку основ інформаційного суспільства та інформаційної економіки:

- сформувався i швидко розвивається вітчизняний ринок інформаційних і комунікаційних технологій, продуктів і послуг;

- сформовано співтовариство компаній i фірм, які провадять професійну діяльність на ринку ІКТ та обслуговують усі сегменти цього ринку;

- українськими компаніями накопичено певний досвід реального виробництва товарів і послуг, які використовують сучасні ІКТ;

- створено базис для законодавчого та нормативного забезпечення розвитку IKT;

- комп'ютеризовані багато галузей господарства, зокрема банківська сфера і сфера державного управління; у суспільній думці складається розуміння актуальності завдання використання ІКТ в реальному бізнесі, у політиці та управлінні, охороні здоров'я і культурі, в науці та освіті тощо.

Неоднозначно і суперечливо виявляється вплив глобалізації на розвиток інформаційної економіки в Україні. Це можна пояснити загостренням міжнародної конкуренції, а також посиленням розриву в інформаційній сфері між розвиненими країнами та країнами, які розвиваються. Одним зі способів подолання наявних проблем i протиріч $\epsilon$ інтеграція України у світовий інформаційний простір, 
використання спільного конкурентного потенціалу, формування єдиного правового простору для формування інтеграційної інформаційної економіки.

Для активізації процесу формування економіки інформаційного суспільства в Україні потрібний комплекс заходів за такими основними напрямами:

- реіндустріалізація промисловості на якісно новій технологічній основі;

- інтеграція виробництва, науки i їх утворення на макро- i мікрорівнях;

- доступне кредитування реального сектору, насамперед високотехнологічного;

- посилення уваги держави до фундаментальної науки, включення iï до пріоритетних напрямів розвитку країни;

- застосування ефективних форм державно-приватного партнерства у сфері інновацій, сприяючого в тому числі активізації вітчизняної прикладної науки;

- збільшення фінансового і ресурсного забезпечення у сфері науки і освіти, підвищення престижу середньої і вищої професійної освіти;

- розвиток інфраструктури інформаційно-комунікаційних технологій;

- підвищення інформаційної грамотності населення;

- відмова від нарощування кількісних показників (ВВП, прибутку, споживання) і перехід до якісної оцінки, розвитку, задоволення реальних потреб.

\section{ВИСНОВКИ}

Таким чином, інформатизація $є$ визначальним чинником, який забезпечує нововведення і модернізацію економіки і соціальної сфери. Тому завдання сучасної економічної науки полягає в тому, щоб методологія дослідження інформатизації разом із розвитком людського чинника зайняла належне місце серед найбільш важливих питань соціально-економічного розвитку суспільства.

Система управління економікою в Україні в нових умовах глобалізації інформаційного простору перебуває у процесі змін, що потребує вдосконалення механізму державного управління економікою загалом та інформаційною економікою зокрема; розробки принципово нових підходів до форм і методів управління; визначення науково обгрунтованих нормативно-правових аспектів державного регулювання. Організаційно-економічна структура суб'єктів господарювання в сфері інформаційної економіки в умовах глобалізації й інформаційного 
розвитку вже не відповідає сучасним об'єктивним потребам українського суспільства, тому виникає необхідність у створенні ефективного інформаційного забезпечення суспільства.

Механізми розвитку інформаційної економіки в Україні слід розглядати як механізми державного управління (практичні заходи, засоби, важелі, стимули з боку держави) та недержавні механізми (конкуренцію та партнерство). Реалізація державної політики розвитку інформаційної економіки в контексті інтеграції України в світові ринки, світове суспільство, створення передумов для поглиблення та розширення відносин зі світовим та європейським інформаційним простором актуалізує необхідність науково-аналітичного супроводу цих процесів та удосконалення механізмів реалізації державної політики в управлінні розвитком інформаційної економіки. Зокрема необхідно:

1. Виробити єдині принципи і загальні правила взаємодії всіх суб'єктів інформаційної діяльності при оптимальному співвідношенні державного регулювання та саморегулювання й розвитку інформаційних ринків.

2. Забезпечити умови для безпечної інформаційної взаємодії держави, громадян та організацій.

3. Гарантувати та уможливити рівність у доступі суб'єктів інформаційної діяльності до відкритих інформаційних ресурсів та їхню правову рівність.

4. Збереження балансу інтересів держави і світового співтовариства при входженні України в глобальний інформаційний простір, збереження інформаційного суверенітету.

5. Боротьба з піратством у галузі інформаційних технологій.

\section{АНОТАЦІЯ}

Нині спостерігається тенденція до зростання ролі знань і нематеріальних активів, які зумовлюються формуванням нового етапу економічного розвитку - економіки інформаційного суспільства. Питання формування інформаційного суспільства безпосередньо пов'язане із технологічними інноваціями.

У першому розділі статті розглядаються теоретичні аспекти інформатизації економіки та суспільства. Розкрито визначення інформаційного суспільства та інформаційної економіки, визначені основні риси інформаційного суспільства та ознаки інформаційної економіки. У другому розділі розглянуто механізми розвитку інформаційної економіки в Україні; проведено аналіз сучасного стану інформаційної економіки в Україні, визначено пї проблеми та можливості подальшого розвитку. 


\section{ЛIТЕРАТУРА}

1. Панченко О.А., Панченко Л.В. Інформаційна безпека та інформаційна культура в сучасному інформаційному суспільстві. Правова інформатика. 2015. № 2(46). С. 32-38.

2. Porat M., Rubin M. The Information Economy: Development and Measurement. Wash., 1978.

3. Masuda Y. The Information Society as Post-Industrial Society. Wash., 1981.

4. Stonier T. The Wealth of Information. L., 1983.

5. Katz R.L. The Information Society: An International Perspective. N.Y., 1988.

6. Арістова І.В. Державна інформаційна політика: організаційноправові аспекти : монографія / за заг. ред. д. ю. н., професора О.М. Бандурки. Х. : УВС, 2000. 368 с.

7. Довгань Л.С., Малик І.П. Інституціональні аспекти розвитку інформаційної економіки. Економічний вісник Національного технічного університету Украӥни «Київський політехнічний інститут». 2013. № 10. C. 3-9.

8. Жаворонкова Г.В., Борисюк І.О. Розвиток інноваційних інформаційно-комп'ютерних технологій в Україні. Формування ринкових відносин в Україні. 2008. № 3. С. 68-72.

9. Литвин А.С. Особливості розвитку галузі інформаційних технологій. Актуальні проблеми економіки. 2011. № 11(125). С. 300-307.

10. Плескач В. Проблеми становлення електронних ринків в умовах розвитку інформаційного суспільства. Науково-технічна інформація, 2008. № 2. C. 45-48.

11. Тамбовцев В.Л. Пятый рынок: экономические проблемы производства информации. М. : МГУ, 2006. 127 с.

12. Федулова Л.І. Тенденції розвитку інноваційної політики та іiі вплив на економічне зростання. Економіка і прогнозування. 2011. № 2. C. $63-81$.

13. Журавлева И.А. Информационное общество : учебное пособие. Иркутск : Изд-во Иркут. гос. ун-та, 2013.141 с.

14. Чугунов А.В. Развитие информационного общества: теории, концепции и программы : учебное пособие. СПб : Ф-т филологии и искусств СПбГУ, 2007. 98 с.

15. Бажал Ю. Інформаційна економіка. Роль інформації формуванні ринкової економіки. К. : К.I.C. 2004. С. 33-57 URL: http://www.ekmair.ukma.kiev.ua/bitstream/123456789/2430/1/Bazhal_Infor matsiyna_ekonomika.pdf (дата звернення: 24.05.2020).

16. Роль конвергентных технологий в становлении непрерывного благополучия в неоиндустриальной экономике / Доценко Е.Ю., 
Жиронкина О.В., Агафонов Ф.В., Генин А.Е. Путеводитель предпринимателя. 2016. № 32. С. 65-79.

17. Кристальный Б., Нестеров Ю. Информационное общество, информационная политика, правовая информационная защита. Информационное общество. 1997. № 1. С. 9-12.

18. Про інформацію : Закон України від 02.10.1992 № 2657-XII / Верховна Рада України. URL: https://zakon.rada.gov.ua/laws/show/265712 (дата звернення: 26.05.2020).

19. Про основні засади розвитку інформаційного суспільства в Україні на 2007-2015 роки : Закон України від 09.01.2007 № 537-V. I Верховна Рада України. URL: https://zakon.rada.gov.ua/laws/show/537-16 (дата звернення: 26.05.2020).

20. Про схвалення Стратегії розвитку інформаційного суспільства в Україні : Розпорядження Кабінету Міністрів України; Стратегія від 15.05.2013 № 386-P. URL: https://zakon.rada.gov.ua/laws/show/386-2013\%D1\%80 (дата звернення: 26.05.2020).

21. Атаманчук Г.В. Теория государственного управления : курс лекций. М. : Юрид. лит., 1997. 400 с.

Information about authors: Gnatenko V. S.,

Candidate of Economic Sciences, Member of the Committee on Budget of the Verkhovna Rada of Ukraine 8, Bankova Str., Kiev, 01008, Ukraine 